\title{
History of earthquake studies in Russia
}

\author{
Ruben Tatevossian \\ Joint Institute of Physics of the Earth, Russian Academy of Science, Moscow, Russia
}

\begin{abstract}
To evaluate the completeness of modern knowledge on historical seismicity it is necessary to know the general geopolitical and socio-cultural background in the country. It determines the possibility to record the evidence of an earthquake and conserve the record in original form for a long time-period. The potential duration of historical earthquake study in Russia is assessed based on these considerations. Certain stages of earthquake study in Russia have been detected. Specific problems of seismicity studies of low active areas are discussed as an example of Russian platform. The value of each (even moderate magnitude) event becomes crucial for seismic hazard assessment in such territories. A correct identification of event nature (tectonic earthquake or exogenous phenomena - landslides, karsts, etc.) is practically impossible without using primary sources with detailed descriptions. Occurrence of modern earthquakes can be used to assess the accuracy of historical seismicity knowledge.
\end{abstract}

Key words earthquakes - historical seismicity evaluation of completeness and accuracy of knowledge on seismicity

\section{Introduction}

Understanding of the completeness of modern knowledge on seismic history is essential for correct seismic hazard assessment. Seismic history is carried in earthquake catalogues and events based on macroseismic data present the most long-term part of it: they have a crucial importance, even if the number of events in instrumental catalogues is much more. Traditionally, completeness of a catalogue is evaluated using magnitude-frequency graphs: it is believed that the data for a given time-period is complete in the linear part of graph (for example, Bune and Gorshkov, 1980). Therefore, the completeness of a sample (earthquake catalogue) is evaluated upon statistics calculated on

Mailing address: Dr. R. Tatevossian, Joint Institute of Physics of the Earth, Russian Academy of Sciences, B. Gruzinskaya 10, 123995 Moscow, Russia; e-mail: ruben@uipe-ras.scgis.ru this sample (together with some a priori assumptions). We suspect certain drawbacks in such methodology. For example, the assumption of magnitude-frequency relationship linearity might be wrong for given spatial and temporal frames of study (even if it is true for the seismicity in a whole). In this paper, the potential duration of historical earthquake studies in Russia is assessed analysing the geopolitical and socio-cultural conditions in the country.

History of earthquake study is not simply a sequence of publications of earthquake catalogues; first of all, it is a development of ideas, general approaches and techniques. To understand stateof-the art and future perspectives, the history of macroseismic studies in Russia is analysed.

Macroseismic studies are of special importance for seismic hazard assessment of low active territories, because instrumentally recorded events are very few or absent. Regional seismometric networks usually are far from low active areas and when the network registers small or moderate earthquakes, accurate data processing is very difficult. In platforms, especially near large rivers, the problem is complicated by the presence of active exogenous phenomena (landslides, karsts), which can produce false events in earthquake catalogues. 
The goals of the paper are: i) to evaluate the potential historical duration of earthquake studies in Russia independent from catalogue statistics; ii) to present history, state-of-the-art and perspectives of macroseismology; iii) to discuss specific problems of earthquake studies in low active territories.

\section{Potential «duration» of historical earthquake studies in Russia}

To be able today to study an earthquake which occurred in the past it is necessary for the information on its effects to have been recorded, conserved in the original form for a long time-period and this information has to be accessible now. Existence of the whole informative chain depends on geopolitical and socio-cultural conditions. For example, the presence of written language, i.e. the capability of people of writing and so to leave written records, essentially raises the chances of recording the earthquake. A high cultural level of society provokes interest in natural phenomena: in such society there is a good chance that even moderate earthquakes will be reported as something worth mentioning. Frequent invasions of enemies and damage caused by invaders, dramatically decrease the possibilities of records surviving for a long time.

The summary of territorial changes of the Russian state starting from the time of its foun-



Fig. 1. Territorial expansion of the Russian state: a - the first Russian state formed in the 9th century (Kiev Russia); $\mathrm{b}$ - independent Russian princedoms established in the next 300 years (Moscow princedom was founded in 1147); $\mathrm{c}$ - Russia after forming the centralised state (beginning of the 17th century); $\mathrm{d}$ - territories included in Russia in 17 th century (up to 1689); e - Russia before the World War I; f - regions under strong influence of Russia at the beginning 20 th century. Dates of two events discussed in this paper are shown: 1839 - a falsequake from Volga River basin; 2001 - a moderate magnitude event on the southern part of Russian platform. Verniy (modern Alma-Ata) is indicated in relation with the earthquake of 1887 presented as example of preinstrumental stage of earthquake studies in Russia. Numbers on map stand for: 1 - Eastern Carpathia; 2 - Crimea; 3 - Eastern Anatolia and Caucasus. 
dation up to 20th century is compiled based on information from Schmidt (1998), Volodikhin (1995), Volodikhin (1997) and Zalesskiy et al. (2001) (fig. 1). The first Russian state was formed (Kiev Russia, 9th century) on practically aseismic areas of the East-European platform: region of Kiev - Chernigov - Pereslavl. During the following 300 years several independent princedoms appeared on the Russian platform (Smolensk, Novgorod, Vladimir-Suzdal, Ryazan, Murom, Moscow): so the development was toward practically aseismic regions. To the end of this period Russia lost its independence and underwent Mongol-Tatar rule. The next step of its territorial expansion occurred after regaining independence and forming a centralised state ( 15 th-16th centuries). For the first time, Russia occupied some seismoactive lands. As a result of the next expansion seismoactive territories compose its considerable part (Baikal, Kamchatka, Far East), though these areas were very poorly populated. Since that time, Russia permanently expanded its territory and before World War I it became one of the most seismoactive countries in the World. The Russian Empire included such seismoactive regions as Eastern Carpathia, Caucasus, Crimea, Eastern Anatolia, Central Asia, Baikal, Altai, Sayans, Kuril Islands, and Kamchatka; under its influence were Northern Iran and a large part of Mongolia and Northern China. From consideration of spatial changes in Russia more or less regular occurrence of earthquakes on its territory could be expected starting from 1700s. Before that time these territories might also be active, as later on, but they were out of Russia, which gives little chance to have a record of this activity in Russian sources. Spatial changes are not the only important ones. Favourable conditions for recording earthquake macroseismic effects and conserving the record are necessary. Some socio-cultural events in Russia affecting these conditions are listed in table I. The information is extracted from Schmidt (1998), Volodikhin (1995), Volodikhin (1997) and Zalesskiy et al. (2001). Compilation of table I stopped at 1862 because of the foundation of the Rumyantsev public library, which was later transformed into the Russian State Library. The library subscribted to all the newspa- pers and bought a copy of each book published in Russia. Since that time we have a reliable place where written sources are stored.

Table II presents the information directly related to the safety of historical materials. Data on all 14 Federal State Archives of Russia is given: date of archive foundation, time period for which it contains documents and amount of documents is indicated. Information is taken from the website: http://www.rusarchives.ru/federal/list.shtml.

Tables I and II display that starting from 1700s conditions were favourable for regular recording of earthquake reports. At the same time, some events (table I) give evidence that even a century later omissions in catalogues are not excluded because of unrecoverable losses of information, particularly because of fires.

\section{Main stages of earthquake studies}

History of earthquake study has never been a permanent progressive flow of ideas, methods and achievements. To make the presentation of history of earthquake studies in Russia better structured certain stages are marked out.

\subsection{Preinstrumental / geographical stage (1850-1902)}

In the second half of the 19th century a number of destructive earthquakes occurred in the territory of the Russian Empire and in the vicinity of its borders: Ararat, 1840; Shemakha, 1859; Erzrum, 1859. They attracted professional and public attention, first of all by numerous victims and destruction (Abich, 1862). As an example of earthquake study of this stage we present the publication of Mushketov (1890) on Verniy earthquake, June 9 (May 28 - old style), 1887. The earthquake was so destructive that special plans to move the regional capital city of Verniy (modern Alma-Ata) elsewhere have been prepared. Hardly any modern publication can be compared with the accuracy with which Mushketov collected and presented the materials on the earthquake. Map of Verniy city and a complete list of all buildings (including construction type) with detailed description of damage are presented in the publication. 
Today this information could be used for microzoning of Alma-Ata. Descriptions are proved by a number of photos of rather high quality (fig. 2). Data on all localities are summarised in the concluding table, which is reproduced here in table III. This table contains data, which let us to step from seismic hazard to seismic risk assessment.
The description of macroseismic effects in full scale (and not only maximal effects extracted from the general context) makes it possible today to apply modern statistical methods of data processing.

With the same accuracy and completeness are documented manifestations of the earthquake in natural environment (fig. 3).

Table I. Social and cultural events in Russia affecting the historical earthquake studies.

\begin{tabular}{|c|c|}
\hline Data & Event \\
\hline 10th century & Slavonic written language entered Russia (988-Christening of Russia). \\
\hline 1037 & $\begin{array}{l}\text { Compilation of first Russian chronicle in Kiev. Total number of known Russian } \\
\text { chronicles: } 1500 \text {; only } 35 \text { of them have survived, they are published in the Complete } \\
\text { Collection of Russian Chronicles (1841-1982). }\end{array}$ \\
\hline 1147 & $\begin{array}{l}\text { Moscow founded; in } 1177 \text { fire practically completely destroyed the town. } \\
\text { Later on, this happened several times. For example, even } 30 \text { years after the fire in } \\
1571 \text {, the territory of Moscow was at least two times less and the population was } 8 \\
\text { times less than before that. This lasted up to } 1820 \text { s, when stone/brick buildings start- } \\
\text { ed to be built instead of wooden ones. }\end{array}$ \\
\hline 1408 & $\begin{array}{l}\text { First All-Russian Chronicle was compiled. It burnt down in fire in } 1812 \text { together with } \\
\text { the whole collection of manuscripts of Moscow Society of History and Russian An- } \\
\text { tiquity. }\end{array}$ \\
\hline $1460 \mathrm{ca}$ & $\begin{array}{l}\text { Moscow becomes the capital of Russia. Since that time historical documents and } \\
\text { archives have been accumulated there up to the time when new capital was built in } \\
1703 \text {. }\end{array}$ \\
\hline 1 March 1564 & First Russian printed book was published. \\
\hline 1621 & $\begin{array}{l}\text { First hand-written newspaper was published (only a few issues appeared in one } \\
\text { copy). }\end{array}$ \\
\hline 1626 & The largest Kremlin archive in Moscow burnt down. \\
\hline 1681 & First Russian high educational institution was established. \\
\hline 15 Dec 1702 & First issue of a regularly printed newspaper appeared. \\
\hline 16 May 1703 & $\begin{array}{l}\text { St. Petersburg was founded - future «capital» of Russian Academy of Science, Russ- } \\
\text { ian Geographical Society, Permanent Central Seismological Commission. }\end{array}$ \\
\hline 1714 & First public library in St. Petersburg was opened. \\
\hline 1724 & First «professional» Russian archive - Archive of Ministry of Foreign Affairs. \\
\hline 27 Dec 1725 & Russian Academy of Sciences was founded in St. Petersburg. \\
\hline 1728 & First scientific Russian archive - Archive of Academy of Sciences. \\
\hline 1755 & University of Moscow was founded; its public library opened in 1756. \\
\hline 1812 & $\begin{array}{l}\text { Napoleon's occupation of Moscow, which leads to great damage to written sources. } \\
\text { From } 20.5 \text { thousands of books and manuscripts of the Moscow University library on- } \\
\text { ly } 51 \text { books and } 12 \text { manuscripts survived. }\end{array}$ \\
\hline 1862 & $\begin{array}{l}\text { Rumyantsev public library founded in Moscow (today Russian State Library). In } \\
1995 \text { it retained } 39000000 \text { items. }\end{array}$ \\
\hline
\end{tabular}


Table II. Federal archives of Russia (sorted by date of reported materials).

\begin{tabular}{|c|c|c|c|}
\hline Place & Archive & $\begin{array}{l}\text { Foundation year/ } \\
\text { Period covered }\end{array}$ & $\begin{array}{l}\text { Amount of } \\
\text { documents }\end{array}$ \\
\hline \multirow[t]{11}{*}{ Moscow } & Russian State Archive of Ancient Acts & $\begin{array}{c}1918 \\
\text { 11th cent.-1917 }\end{array}$ & 3313000 \\
\hline & Russian State Archive of Military History & $\begin{array}{c}1925 \\
1520-1918\end{array}$ & 3428676 \\
\hline & Russian State Archive of Literature and Arts & $\begin{array}{l}1941 \\
\text { 18th cent.-1994 }\end{array}$ & 1101400 \\
\hline & $\begin{array}{l}\text { Russian State Archive of Social and } \\
\text { Political History }\end{array}$ & $\begin{array}{c}1919 \\
1760-1993\end{array}$ & 1649647 \\
\hline & State Archive of Russian Federation & $\begin{array}{c}1920 \\
1800-2000\end{array}$ & 5447137 \\
\hline & Russian State Archive of Audio Documents & $\begin{array}{c}1932 \\
1898-2001\end{array}$ & 200000 \\
\hline & Russian State Military Archive & $\begin{array}{c}1920 \\
1917-1991\end{array}$ & 3393110 \\
\hline & Russian State Archive of Economics & $\begin{array}{c}1961 \\
1917-1994\end{array}$ & 4098718 \\
\hline & $\begin{array}{l}\text { Russian State Archive of Film and } \\
\text { Photo Documents }\end{array}$ & 1918 & 863569 \\
\hline & Russian State Archive of Modern History & $\begin{array}{c}1921 \\
1922-1991\end{array}$ & 1232000 \\
\hline & Russian State Archive of Science and Technology & 1995 & $?$ \\
\hline \multirow[t]{2}{*}{ St. Petersburg } & Russian State Archive of Navy & $\begin{array}{c}1827 \\
1659-1940\end{array}$ & 1218103 \\
\hline & Russian State Historical Archive & $\begin{array}{c}1922 \\
\text { late 18th cent.-1920 }\end{array}$ & 6576620 \\
\hline Vladivostok & Russian State Historical Archive of the Far East & $\begin{array}{c}1943 \\
1722-1998\end{array}$ & 500635 \\
\hline
\end{tabular}

Specialists who studied contemporary earthquakes at such high professional level could not accept that each catastrophic earthquake has to be investigated as some random natural phenomenon. They wanted to find certain regularities in spatial and temporal distribution of earthquakes: for this, it was necessary to build earthquake catalogues, which reflect seismic history for as long a time as possible. In 1893, the first comprehensive catalogue of Russian earthquakes was published (Mushketov and Orlov, 1893); it included events up to 1887 . In the In- troduction, Mushketov and Orlov explained the reasons why such a catalogue is necessary. These reasons show how little things have been changed since that time. In principle, they might be copied and passed to any applications of seismological project today. Here are the first two sentences of their Introduction:

«Destructive earthquakes recurring from time to time within the Russian boundaries or neighbouring countries often arouse the interest of Russian society and government; each time when such cases happen, expeditions were sent to study 
Table III. Summary table of damage and losses report of 1887, Verniy earthquake compiled by Mushketov (1890).

\begin{tabular}{|c|c|c|c|c|c|}
\hline \multirow[t]{2}{*}{ Locality } & \multirow[t]{2}{*}{ Population } & \multirow{2}{*}{$\begin{array}{l}\text { Number of } \\
\text { buildings } \\
\text { before the } \\
\text { earthquake }\end{array}$} & \multirow{2}{*}{$\begin{array}{c}\text { Number of } \\
\text { destroyed, or } \\
\text { heavily damaged } \\
\text { buildings }\end{array}$} & \multicolumn{2}{|c|}{ Losses in roubles of } \\
\hline & & & & Real estate & $\begin{array}{c}\text { Moveable } \\
\text { property }\end{array}$ \\
\hline City of Verniy & 21000 & 1799 & 1798 & 1136889 & 476400 \\
\hline $\begin{array}{l}\text { Village B. Almatin- } \\
\text { skaya together with } \\
\text { M. Almatinskaya }\end{array}$ & 6491 & 972 & 347 & 331930 & 26225 \\
\hline Lubovniy & 1293 & 232 & 25 & 25792 & 8135 \\
\hline Kazansko-Bogorodskoe & 959 & 120 & 118 & 21571 & 387 \\
\hline Sofiyskaya & 3568 & 576 & 265 & 10867 & 298 \\
\hline Nadezhdinskiy & 2239 & 313 & 52 & 800 & 60 \\
\hline Mikhailovskoe & 1352 & 487 & 55 & 331 & - \\
\hline Malovodnoe & 242 & 70 & 15 & 331 & - \\
\hline Zaitsevskoe & 1393 & 332 & 46 & 637 & - \\
\hline Karasuyskoe & 21 & 16 & 15 & 897 & - \\
\hline Kutentaiskoe & 102 & 18 & 18 & 375 & - \\
\hline Iliyskiy & 275 & 73 & 15 & 1313 & - \\
\hline Sazanovskoe & 1111 & 137 & 22 & 3495 & - \\
\hline Uital & 178 & 27 & 1 & 290 & - \\
\hline Total & 40394 & 5172 & 2792 & 1535518 & 511505 \\
\hline
\end{tabular}
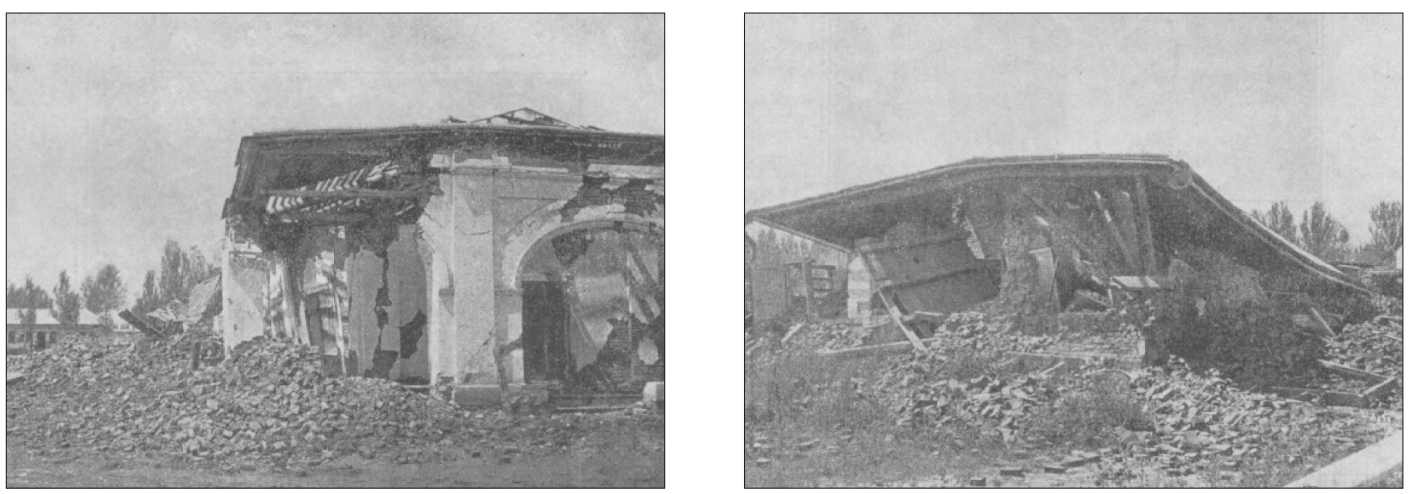

Fig. 2. Example of documentation of damage in Verniy (photos from Mushketov, 1890). We can clearly see the type of construction and damage. 
the destructive consequences of earthquakes, with the idea of establishing permanent seismic observations, even money has been found to alleviate the results of natural calamity. But, alas, regardless of such temporary excitation, earthquake study in Russia did not go forward, and interest toward them gradually subsides, as soon as underground shocks calm down». The goal of the catalogue was formulated by the same authors as follows: «Protection from earthquakes is impossible without knowledge of their geographical distribution». (Note that here and elsewhere citations and descriptions in English are translated from Russian by the author).

It is not by chance that the Imperial Russian Geographical Society became the sponsor and organiser of the seismological studies. So, this period of pre-instrumental stage we can also call the period of geographical seismology.

Mushketov and Orlov (1893) discussed the problem of catalogue completeness. They compiled a table which is reproduced here (table IV). Completeness is evaluated based on analysis of sources of information. Never after that in Russian catalogues of historical seismicity (including recent ones) has such an analysis been presented. Very impressive is also the size of territory for which information on earthquakes was presented. Only 80 years later in the USSR a large team from all seismological institutions all over the country could carry out a project in which spatial frames might be compared with the area covered by the catalogue of Mushketov and Orlov.

The catalogue is descriptive. Sources of each entry are given. This was the first catalogue of Russian Empire earthquakes, so the authors were not able to copy and post entries from other earlier published catalogues (except for earthquakes in boundary regions). As a result, the work is based mainly on primary sources (archive materials, newspapers, etc.).

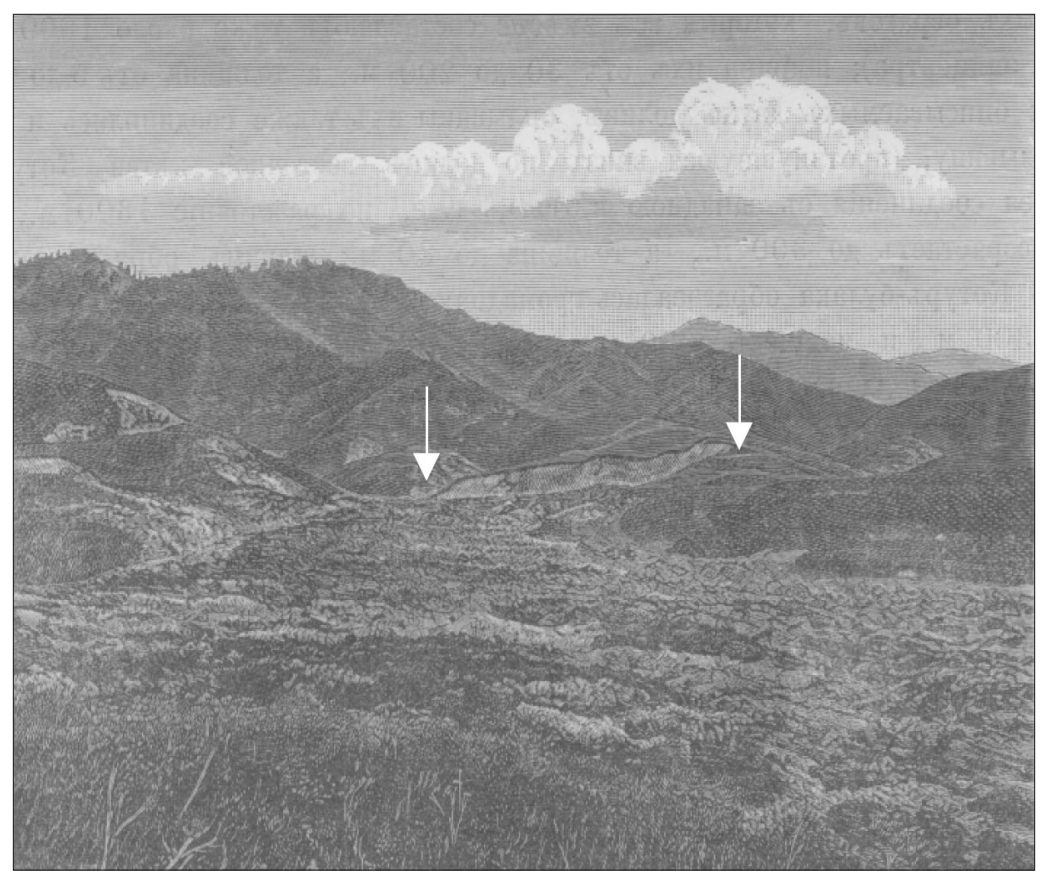

Fig. 3. Example of documenting macroseismic effects on natural environment (photo from Mushketov, 1890). Arrows point the edges of the landslide. 
Table IV. Evaluation of data completeness of the earthquake catalogue from Mushketov and Orlov (1893).

\begin{tabular}{lcccc}
\hline \multicolumn{1}{c}{ Region / Country } & $\begin{array}{c}\text { Year of } \\
\text { first entry }\end{array}$ & $\begin{array}{c}\text { Year from which } \\
\text { regular information } \\
\text { is available }\end{array}$ & $\begin{array}{c}\text { Total event } \\
\text { number }\end{array}$ & $\begin{array}{c}\text { Event number } \\
\text { in regular part }\end{array}$ \\
\hline China & 596 B.C. & 1485 & 710 & 558 \\
Eastern Siberia & 1700 & 1700 & 549 & 549 \\
Western Siberia & 1734 & 1761 & 36 & 35 \\
Caucasus & 715 & 1801 & 590 & 555 \\
$\begin{array}{l}\text { Central Asia together with Bukhara } \\
\text { and Khiva }\end{array}$ & 1716 & 1820 & 202 & 200 \\
North of European Russia & 1670 & 1742 & 27 & 26 \\
Urals & 1788 & 1788 & 20 & 20 \\
European Russia & 1000 & 1807 & 148 & 111 \\
$\begin{array}{l}\text { Turkish and Persian territories } \\
\text { adjacent to Caucasus }\end{array}$ & 1843 & 1843 & 121 & 121 \\
\hline
\end{tabular}

But this was not a special goal of compilers: when it was possible to use information from published catalogues (Abich, 1882; Perrey, 1843; Mallet and Mallet, 1858) they did.

The milestone achievements of this stage are comprehensive studies of contemporary strong earthquakes and compilation of the first descriptive earthquake catalogue of the Russian Empire. It is natural to put the end of the preinstrumental stage in 1902, when in St. Petersburg the Permanent Central Seismological Commission (PCSC) had been established the main goal of which was organisation of instrumental observations.

\subsection{Early instrumental stage (1902-1914)}

Before the foundation of PCSC, the Temporary Seismological Commission acted for one year using as a model the corresponding British service. Since 1902 annual bulletins have been published. The first one included data from five seismic stations (Irkutsk, Nikolaev, Tashkent,
Tiflis, Yurev) and from two astronomic observatories where seismological observations were carried out (Kharkov and Pavlovsk) (Levitski, 1902). The instrumental observations were started by specialists who had great experience in macroseismic investigations. Probably because of that, macroseismic and instrumental data were put in bulletins together. This reflects the assumption of the fact, that the object of study - earthquake - is unique, so for its comprehensive understanding it is necessary to describe different manifestations of the events, including macroseismic effects. Alas, such an «integrated» understanding of the problem was soon lost: seismologists had an impression (partly illusionary) that the instrumental data are much more accurate and absolutely sufficient for comprehensive earthquake investigation. When the changes in PCSC administration in 1912 macroseismic information had a supplementary role.

The most important achievement at this stage of earthquake study was in putting the instrumental and macroseismic data collec- 
tion, systematisation, conservation and distribution on a regular basis. As an end of the stage, the year 1914 could be pointed when the sequence of political and social shocks followed: World War I, Revolutions, Civil War, which practically blocked earthquake studies in Russia up to mid 1920s. We can call the period 1914-1925 as an empty one for Russian seismology.

\subsection{Regional stage (1925-1961)}

Because of hard socio-economic situation (also, probably, because of the absence of a leader) it was impossible to organise large AllUnion projects comparable spatially with the Mushketov and Orlov catalogue. But interest in seismic history in mid 1920s was very high. It was warmed by occurrence of such destructive earthquakes as Leninakan (1926) and Crimea (1927). The investigations of that time were on a regional scale. A number of catalogues on the seismic history of Armenia (Stepanyan, 1942), Azerbaijan (Malinovskiy, 1935), Lesser Caucasus (Bius, 1948), Turkmenia (Gorshkov, 1947) and many others had been compiled. As an example of regional catalogue, publication of Bius (1948) is presented.

Bius (1948) is a descriptive catalogue, though it already contains the very first step toward parameterisation. Earthquake parameters are not determined, but for many cases intensities in localities are evaluated in degrees of macroseismic scale. Bius used the MCS intensity scale, a description of which he included in the Introduction. This was the most widely used scale in the 1940s. Macroseismic scales are an important part of quantitative description in earthquake studies; their development is an inherent and essential part of the history of earthquake studies. But this is such a huge and specific problem that requires a special analysis in separate paper: here we will only mention which scales were used in particular studies.

At this stage, investigators met several problems, hard for historical seismology also today. Bius put in the introduction to the catalogue a table of localities, which had been renamed for political reasons (first of all because of the revolution of 1917). This is another example of how tightly the geopolitical and socio-cultural background in the country is linked to studies of past earthquakes. To give an impression of the problem a table from Bius (1948) is reproduced here (table V). It has to be stressed that these are renamings of localities only in Lesser Caucasus before 1948 (and, as pointed by Bius, the list is not complete even for them). Since that times at least three waves of renamings have passed: today only very few localities carry the same name as is written in column «Modern name» of table V. A lot of names in original sources cannot be identified today.

Sources are given for each entry in the catalogue. Using primary sources was not considered something of special importance. Because the time before 1887 is covered by the Mushketov and Orlov catalogue, it comprises the basic (and often the single) source of information for earthquakes of that time. But for a later time Bius had to work mainly with primary sources (there were no published catalogues, except those of Stepanyan (1942) and Malinovskiy (1935) from where data on Armenian and Azerbaijan earthquakes could be copied).

The main achievement of this stage was compilation of several regional catalogues. They guarantee (as much, as they could) continuity of macroseismic information accumulation, which was started by Mushketov and Orlov in the 1850s. The basis for the next stage of earthquake study was formed. The problem appeared in this stage is related to the scale level of works. In each region, data was collected, systemised and analysed according to different procedures. It leads to accumulation of inhomogeneous materials (though, rather homogeneous within the same region). The end of this stage is marked by publication by Shebalin (1961) of the paper titled «Intensity, magnitude and source depth of earthquakes» in the first issue of «Earthquakes in the USSR» which later on became annual. From this publication started the era of parametric macroseismic catalogues in Russia. 
Table V. List of renamed localities in the region of Lesser Caucasus from Bius (1948).

\begin{tabular}{|c|c|c|c|}
\hline Modern name & Old name/names & Modern name & Old name/names \\
\hline Agara & Tanatubani & Mikha Tsakhakaya & Akhalsenaki \\
\hline Alabashly & Karaery & Mikuzani & Dzegani \\
\hline Aragats & Alagez & Nazarashen & Gaji Nazar Kuli \\
\hline Arbat & Perekeshkul & Oktomber & Sardarabad \\
\hline Bogdanovka & Khojabeki & Psirtskha & Noviy Afon \\
\hline Gavazy Upper & Bezhany & Rozenfeld & Marienfeld \\
\hline Gashperdy & Akhakhibula & Sabirabad & Petropavlovka \\
\hline Gegechkori & Martvili; Naogalevi & Sevan & Elenovka \\
\hline Goris & Gerusy & Stalinir & Tskhinvali \\
\hline Dmitrovka & Salim & Stepanavan & Jelalogly \\
\hline Erevan & Erivan' & Stepanakert & Khankendy \\
\hline Ijevan & Karavansaray & Tabatskuri & Kizilkilisa \\
\hline Kalinino & Vorontsovka & Tbilisi & Tiflis \\
\hline Karadonly & Bagramtapa & Tejisi & Minasaskend \\
\hline Karyagino & Karabukag; Sardar & Khanlar & Elenendorf; Elenino \\
\hline Kirovabad & Gyanja; Elisavetpol' & Kharagouli & Belogory \\
\hline Kirovakan & Big Karakilis & Khashuri & Mikhailovo \\
\hline Krasnye Kolodtsy & Tsarskie Kolodtsy & Khilly & Bozh’i Promysla \\
\hline Krasnoselsk & Krasnoe Selo; Mikhalovka & Tsalka & Barmaksiz \\
\hline Kulevi & Redut Kale & Tsebelda & Zalharovka \\
\hline Maylya & Kumani (island) & Tsulukidzhe & Khoni \\
\hline Leninakan & Aleksanropol & Chaikend & Mikhailovka \\
\hline Likhi & Varvatino & Shamkhor & Annenfeld; Annino \\
\hline Bolnisi & Luksemburg; Ekaterinenfeld & Shorzha & Nadezhdino \\
\hline Martuni & Khonashen & Shaumyany & Shulavery \\
\hline Makharadze & Ozurgeti & Shroma & Mikel Gabriel \\
\hline Mayakovskiy & Bagdadi & & \\
\hline
\end{tabular}

\subsection{Parametric stage (1962-1982)}

The paper by Shebalin (1961) not only suggested a set of formulae (macroseismic field equations) which can be used to determine earthquake parameters based on initial macroseismic information but also formulated ideology of parametric catalogue compilation. The basic principle of the ideology was the following: any communication on an earthquake, regardless to its completeness and reliability, can and must be parameterised into the catalogue entry. The only problem is in a reasonable evaluation of accuracy of parameterisation. The most complete realisation of this principle is found in one of the largest seismological projects in the USSR - (Kondorskaya and Shebalin, 1977). An American version of the catalogue was published in 1982 (Kondorskaya and Shebalin, 1982) which included corrections and addenda to the Russian edition made by catalogue editors. This publication is considered a most prominent achievement of this stage and, at the same time, it marks the end of the stage. 
From the previous stage the catalogue inherited the regional principle of organisation: in fact, under one cover page are published 14 catalogues, each of them has its own team of compilers and editors and separate list of sources. Nevertheless, chief editors were able to establish a high level of standardisation in data processing and presentation of results. The catalogue has a general introduction, parametric part, textual descriptions of the most important events, list of sources. As a supporting dataset compilers prepared an «Atlas of isoseismals» (Shebalin, 1974) also compiled according to the regional principle, and never published because of financial and organizational problems. All the intensities in Kondorskaya and Shebalin (1982) and in Shebalin (1974) are given in the MSK64 scale.

Catalogue format and structure are shown for the case of the 31 December 1899 Akhalkalak earthquake. It is the largest seismic event of Javakhet Highland. Information on the Akhalkalak earthquake is presented in the most complete form: its parametric entry and textual description are shown in fig. $4 \mathrm{a}, \mathrm{b}$, an isoseismal map is plotted in the above mentioned, unpublished Atlas (fig. 5). Such catalogue format and structure present complete

(a)
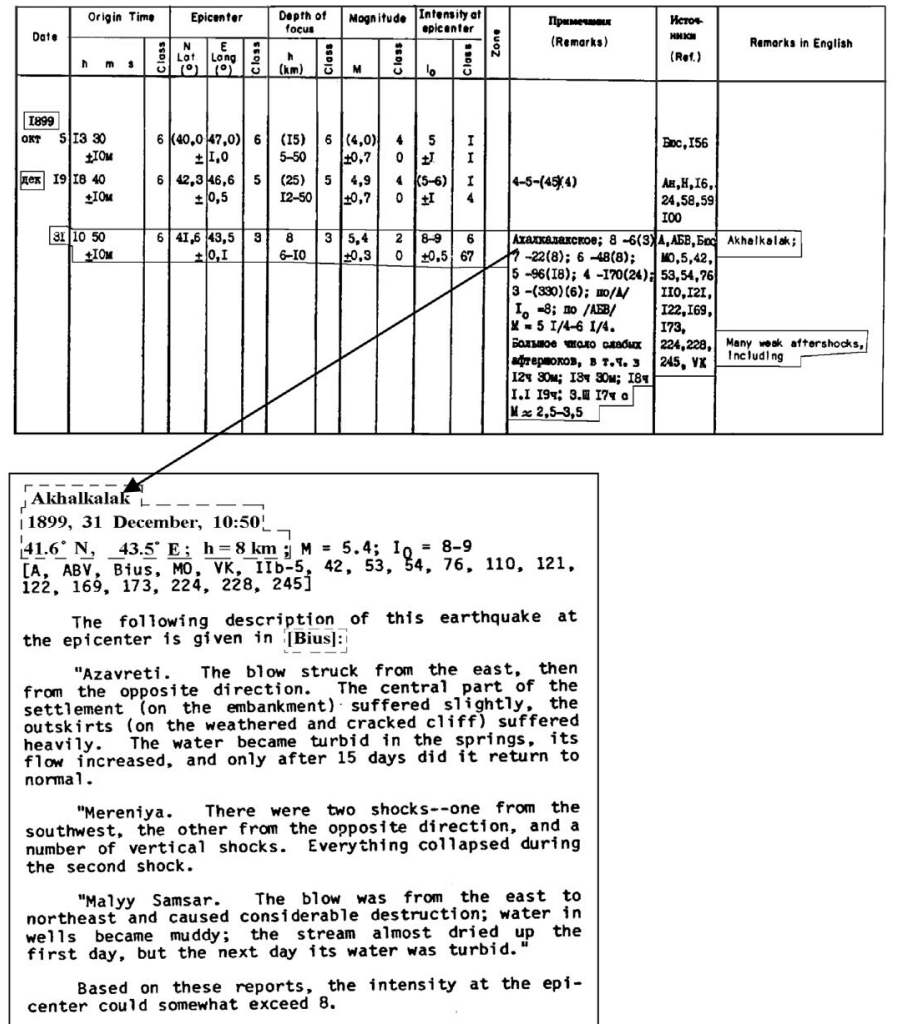

(b)

Fig. 4a,b. Information on 31 December 1899, Akhalkalak earthquake in Kondorskaya and Shebalin (1982): a) parametric entry with remarks and b) description of macroseismic effects, referring to Bius (1948) as its source. 


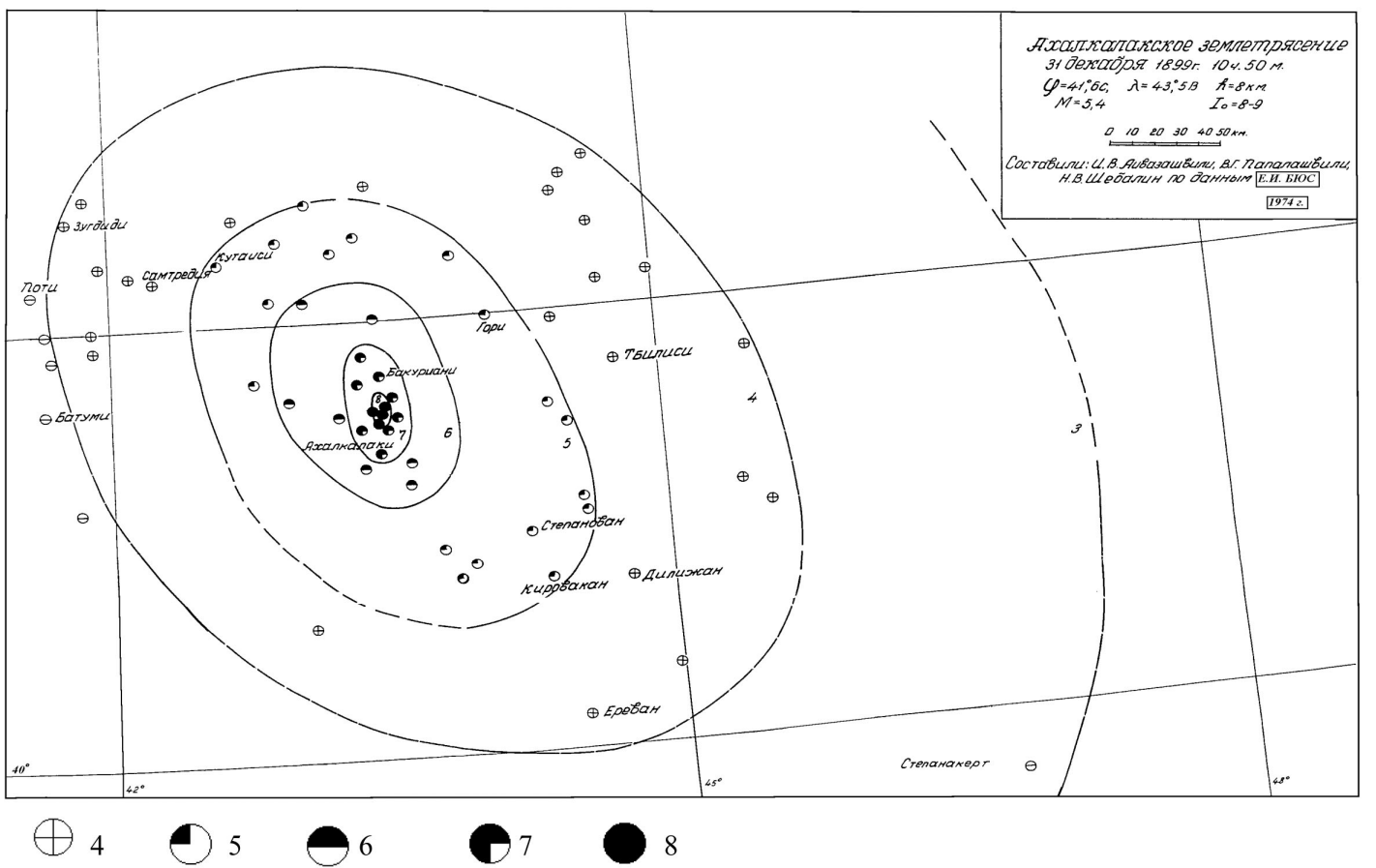

Fig. 5. Isoseismal map of 31 December 1899, Akhalkalak earthquake from unpublished Atlas prepared in 1974 as supporting dataset for Kondorskaya and Shebalin (1982). According to the legend it is based on data from Bius (1948).

information on earthquake and support parameterisation at least for the major events in the given seismotectonic region. The most remarkable achievement of the «total parameterisation principle» was in transformation of macroseismology from a descriptive supplementary seismological discipline into one of the basic methods for quantitative seismic hazard assessment.

\subsection{Modern stage (1982-2002)}

During the modern stage, earthquake studies in the USSR developed in two main directions: extensive (compilation of catalogues for large areas without giving much importance to the study of single entries) and intensive (detailed comprehensive analysis of the major earthquakes). Extensive studies related to large international and Russian projects (Global Seismic Hazard Assessment Program - Shebalin and Tatevossian, 1997; Seismic Zoning of Northern Eurasia - Ulomov, 1993). Any essentially new ideas and methods of catalogue compilation were not developed within the extensive approach. Some corrections of parameters were made; false events excluded and omitted ones added in earlier published catalogues. Usually this was done without referring to newly found original sources of information, so, often it is impossible to guess the reasons for corrections (or, rather, changes). Intensive 
studies were based on understanding of the crucial importance of quality and reliability of information sources on historical earthquakes. Most remarkably these ideas were formulated within the frames of the international project Basic European Earthquake Catalogue and Database (Stucchi et al., 2001). According to them the procedure of earthquake parameterisation has to start from analysis of sources of information done following rigorous historical methods. Procedure of parameterisation itself must be absolutely clear and transparent. Cited sources in the reference list have to be the ones really used for parameter determination and not just copied and passed from other publications. As an example of study in Russia done according to these standards we will present the paper on the Akhalkalak earthquake (Tatevossian et al., 1997). This demonstrates the problems which can arise from a too active implementation of the total parameterisation principle.

Figure 6 from Tatevossian et al. (1997) illustrates the chronology of sources given in Kondorskaya and Shebalin (1982) for the Akhalkalak earthquake. The list of sources includes publications based on field expeditions organised immediately after the earthquake in its epicentral area and several later compilations, many of which do not contain references at all. The list even points to sources published before (!) the occurrence of the Akhalkalak earthquake (obvious misprints). Isoseismal map plotted based on data from primary sources is given in fig. 7 (Tat-

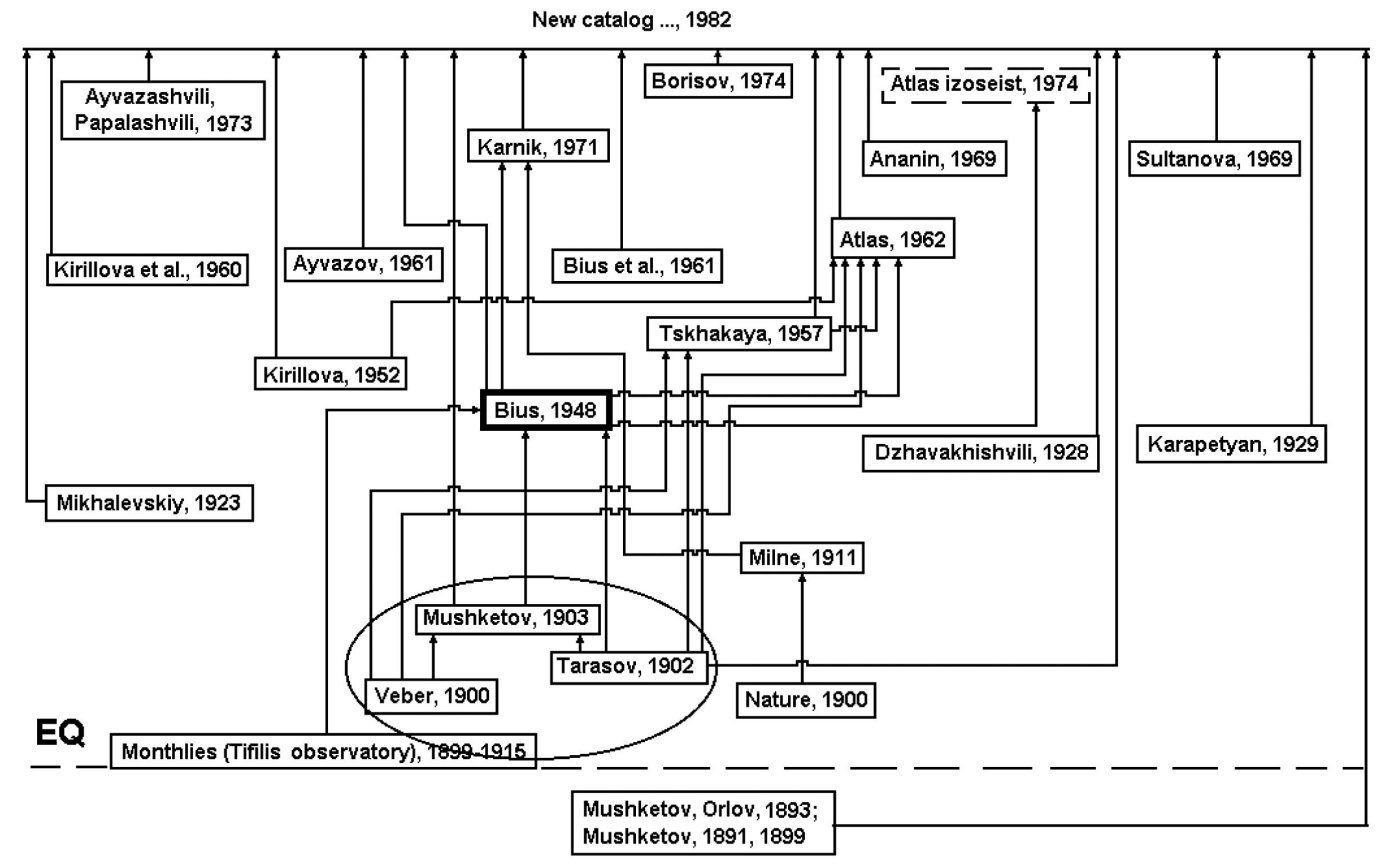

Fig. 6. Chronological scheme (reference-tree) of sources from Kondorskaya and Shebalin (1982) on 31 December 1899, Akhalkalak earthquake compiled in Tatevossian et al. (1997). The catalogue of Bius (1948), which was the basic source for isoseismal map compilation, is shown in a bold rectangle; in a dashed rectangle is Shebalin (1974), which is a ghost root for the catalogue entry; EQ indicates the earthquake origin time; in oval are enclosed sources, which represent primary materials. 


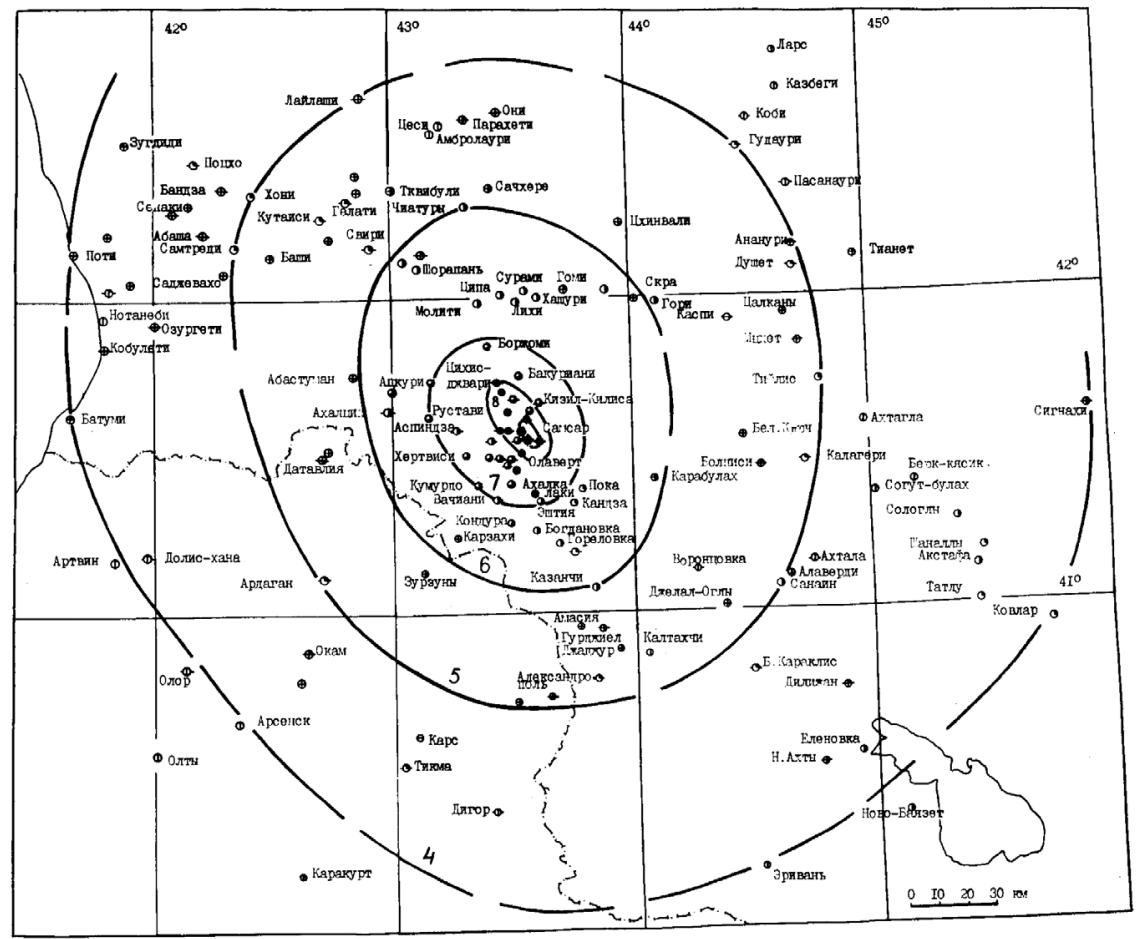

Fig. 7. Isoseismal map of 31 December 1899, Akhalkalak earthquake compiled by N.V. Shebalin and N.G. Mokrushina based on materials from primary sources - see the scheme in fig. 5 (from Tatevossian et al., 1997).

evossian et al., 1997). Comparison with the map in fig. 5 demonstrates that only a small portion of data accessible for this earthquake was used in Kondorskaya and Shebalin (1982), which decreases the accuracy and reliability of parameter assessment.

\section{Specific problems of earthquake studies in the Russian platform}

In case of low seismic activity, the role of each event in the catalogue becomes crucial for seismic hazard evaluation. This is also true for the Russian platform. The question arises of how accurate and complete is our knowledge on seismicity of this large area where the majority of the Russian population live today.
The Salsk earthquake occurred on 22 May 2001, in the southern part of the Russian platform $\left(M_{\mathrm{S}}=4.6\right)$ : it was felt over a relatively large area. The earthquake had the maximum observed magnitude in the region throughout the whole period of historical and instrumental recordings. The seismicity of the epicentral zone before 22 May 2001 was represented only by two shocks with magnitudes 2.7 and 3.2 in 1984 and 1996 correspondingly. A macroseismic survey of the epicentral area of this earthquake was done and its results are published in Tatevossian et al. (2002). Instrumental and macroseismic epicentres are in good agreement; the location error is less than 3-5 km. The position of the Salsk earthquake is shown in corresponding seismic (fig. 8) and geotectonic (fig. 9) settings. Usually, earthquake effects in large cities and administrative 




Fig. 8. Seismic setting of the 22 May 2001 Salsk earthquake from Tatevossian et al. (2002). Earthquake epicentres are plotted according to the Earthquake catalogue of Northern Eurasia (Ulomov, 1993) (circle size is proportional to earthquake magnitude).

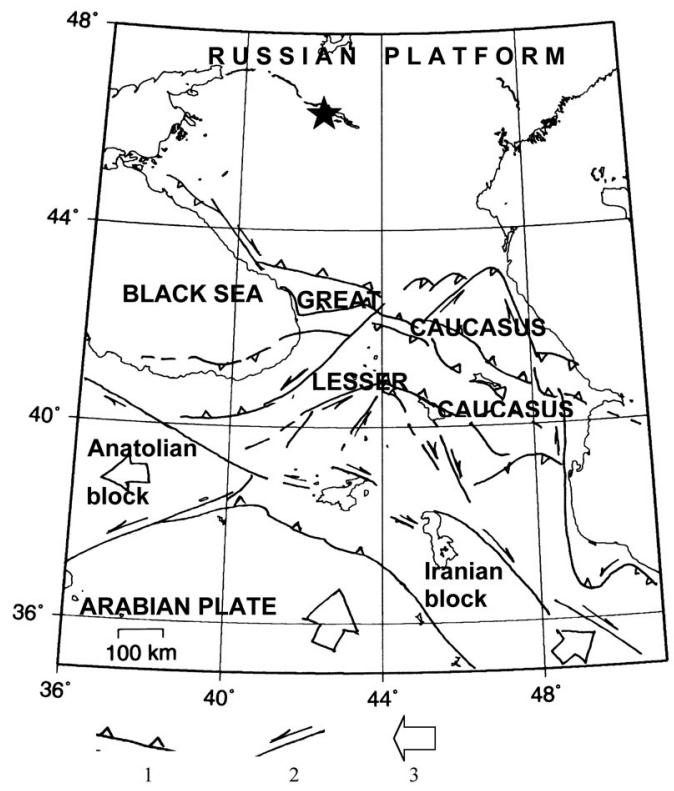

Fig. 9. Tectonic setting of the 22 May 2001 Salsk earthquake from Tatevossian et al. (2002). Tectonic scheme from Rebai et al. (1993) with simplifications: 1 - reverse faults (triangles point to upthrown wing); 2 - strikeslip faults (arrows show direction of motion); 3 - plate motion direction. 




Fig. 10. «Administrative» data filtering. Hypothetical event, which can appear in the regional catalogue after 100 years on the 22 May 2001 Salsk earthquake, if the only information which would survive on that event will be the one collected by Geophysical Service of RAS (Tatevossian et al., 2002). Intensities at the sites are given according to the Geophysical Service, RAS.

centres attract attention in historical sources, though they might be well away from the epicentre and zone of maximum effects. This distorts the figure of spatial distribution of macroseismic effects. Such a distortion because of switching on the «administrative» filter can be found even when we are dealing with modern earthquakes studied by an official seismological body. Immediately after the Salsk earthquake Geophysical Service of RAS rapidly collected information on its felt effects (Geophysical Service of RAS, 2001). The data was acquired from administrative centres. The localities and intensities assessed by the Geophysical Service are shown in fig. 10.

Let us make a mental experiment and assume that the only information which will survive a hundred years after the Salsk earthquake, will be these rapidly collected communications. If the future seismologist processes these data according to the modern standard procedures he will locate the epicentre location $100 \mathrm{~km}$ away from its actual site, deeper source $(15$, instead of $9 \mathrm{~km}$ ) and magnitude 5.6, which is 1 unit more than it really was! And he will be satisfied with the results obtained because the epicentre will move toward the Stavropol Highland where earthquakes of similar moderate magnitudes are known (fig. 8). The location of a false event is also in better agreement with the general geotectonic scheme (fig. 9). And he will be very happy, because only in a few cases do we have today such a lot of information for historical earthquakes of this area: intensities are reported in seven localities (fig. 10).

Those are the measure of distortions associated with «administrative» filter. Another mental experiment can illustrate the effect of a poorly populated area. Imagine that the Salsk earthquake occurred 200 years before its actual time, in 1801: which localities in this region could have felt this earthquake? Only one - Stavropol, which was founded in 1777 ! So, this event either will be omitted in the catalogues, or located as a moderate event somewhere near Stavropol.

Another problem complicating historical earthquake studies in Russia can be illustrated in relation to the Salsk earthquake - a problem of toponymy. During field observations of the Salsk earthquake the macroseismic group visit- 


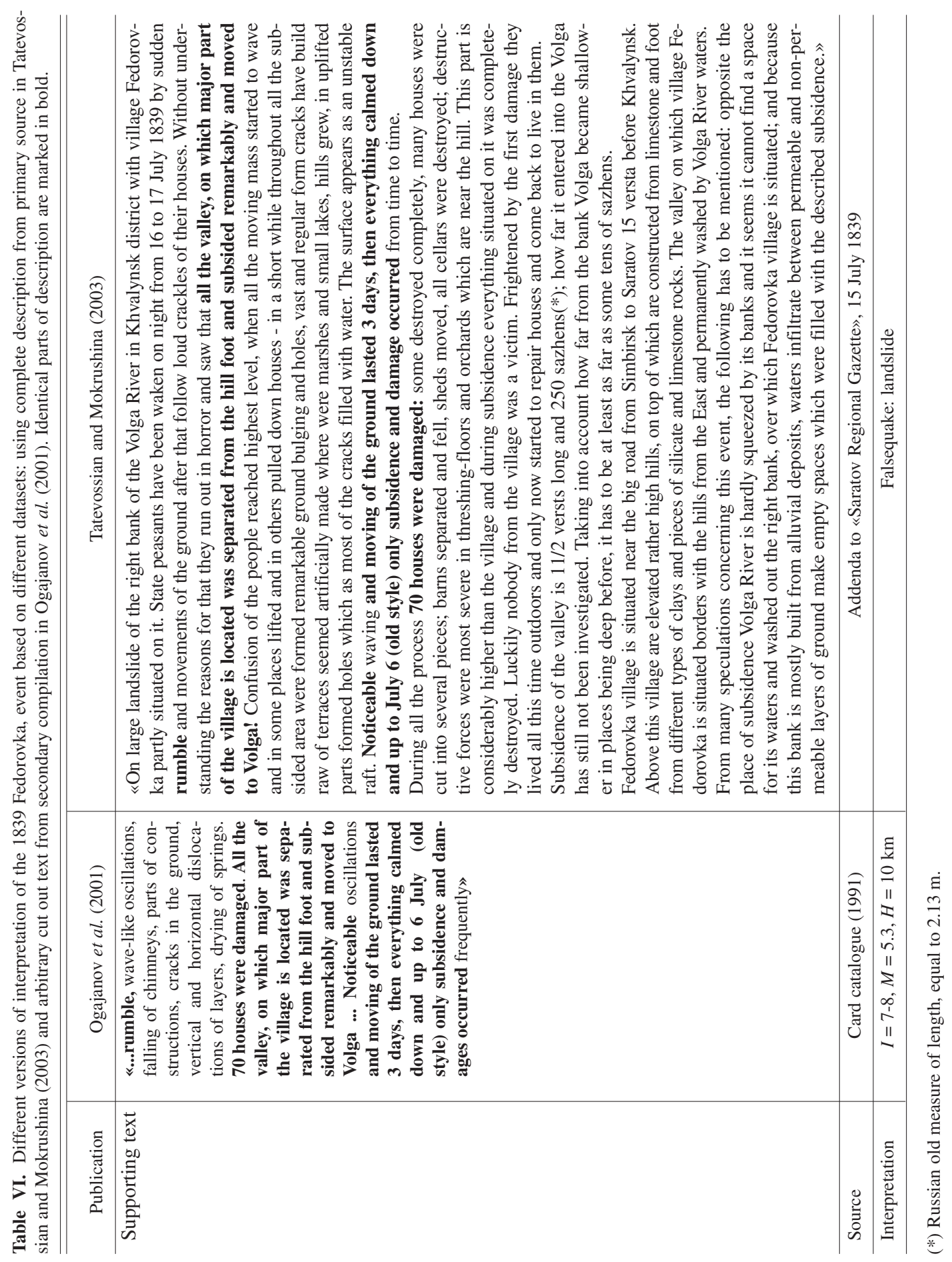


ed four localities named Veseliy. Results of query in World map database (Encarta World Atlas 1998) reveal 184 localities named Veseliy, 26 of which are in the Krasnodar region. If we add to this list also localities with slightly altered names (Veselaya, Veseloe) then we will get 280 items. Certainly this does not make earthquake studies an easy task in Russia.

The problem of earthquake identification is also very hard in platform regions, especially near large rivers. Usually, these are regions of active landslides and other exogenous phenomena, which can produce false earthquakes in catalogues. This complex problem becomes even more complicated when data sources are used improperly. Let us consider the event on 29 June (17 June - old style) 1839 near the village Fedorovka (middle flow of the Volga River). Two solutions on this event together with supporting texts and corresponding sources are given in table VI: the first interprets the data as a tectonic earthquake with magnitude 5.3 (Ogajanov et al., 2001), the second, as a landslide (Tatevossian and Mokrushina, 2003). The same words in both descriptions are marked in bold. The present paper is not intended to discuss all the details of the 1839 event, just note how much more complete and detailed is the description in primary source cited in Tatevossian and Mokrushina (2003) without any omissions.

The description clearly tells that we are dealing with a landslide. Meanwhile arbitrarily arranged cut out pieces of text enable us to suggest that the analysing event might be an earthquake. Note also the year of publication (1991) used as an information source of the earthquake in 1839 in Ogajanov et al. (2001). This shows how dramatically different conclusions can be drawn concerning the same event when secondary sources and arbitrary filtered descriptions are used.

\section{Conclusions}

Russia became a seismoactive country starting from 1700s. More or less from the same time socio-cultural conditions developed favourable as a whole for recording earthquake effects and conservation of the records.
Earthquake studies in Russia developed from compilation of descriptive catalogues toward parametric ones. The remarkable achievement of the principle of «total parameterisation» was in transforming macroseismology from a descriptive supplementary seismological discipline into the leading quantitative method of seismic hazard assessment. But uncontrolled implementation of this principle together with insufficient attention paid to the analysis of information sources decreases the reliability of final evaluations. The following corrections and addenda to earlier published catalogues do not change the situation essentially. New perspectives in historical earthquake studies come from more accurate use of primary sources.

Distortions, which come from a different kind of initial data filtering («administrative», «arbitrary cut out») can play a dramatic role in seismic hazard assessment of the Russian platform. This problem has a little chance of being solved without using complete descriptions from primary sources in earthquake studies.

Since the 1960s historical earthquake catalogue compilation was a part of seismic hazard assessment projects. This organisational background is very unfavourable for earthquake studies: permanent work on collecting and processing of macroseismic data is replaced by sporadic activities. At the moment there are no current special projects in Russia for historical earthquake studies. Some investigators are receiving contracts with organisations interested in hazard assessment, such as the Ministry of Atomic Energy. The main interest is related to low active territories. The case of 1839 event illustrates one of the reasons for that. In no seismoactive region could such large uncertainty in data interpretation be met. According to one interpretation, the maximum observed magnitude is 5.3, according to another interpretation, there was no earthquake at all. Taking into account the short potential duration of earthquake studies in Russia together with possible long recurrence times of earthquakes on platforms, we can easily understand the reasons for speculations concerning the historical seismicity of the Russian platform. It has to be stressed that the overwhelming majority of the Russian population live there. From a certain point of view, the Salsk earthquake $\left(M_{s}=4.6\right)$ 
having the maximum recorded magnitude in the southern parts of the Russian platform, is more informative for hazard assessment, than, say, magnitude 7.5 in the region of the Kuril Islands, where the largest instrumentally recorded event had $M_{s}=8.4$ (Shikotan 1969 earthquake).

\section{Acknowledgements}

Special thanks to Max Stucchi, who initiated this work. It was partly supported by RFBR 0205-64894 grant. This publication would have been impossible without discussions with and comments received from N.G. Mokrushina, F.F. Aptikaev, Zh. Ya. Aptekman, and S.S. Arefiev.

\section{REFERENCES}

AвICH, H. (1862): Earthquakes in Shemakha and Erzrum on May 1859, Zapiski RGO, 5 (in Russian).

AвICH, H. (1882): Geologie des Armenischen Hohlandes Westhalfte, in Geologische Forschungen in den Kaukasischen Ländern, Wien.

Bius, E.I. (1948): Seismic conditions of the Lesser Caucasus, Part I, Chronology of earthquakes in the Lesser Caucasus pp. 304 (in Russian).

Bune, V.I. and G.P. GorshKov (Editors) (1980): Seismic zoning of the USSR territory (Nauka Moskow), pp. 306 (in Russian).

GeOPHYSICAL SERVICE OF RAS (2001): Information on the Salsk earthquake of May 22, 2001 (on line: http://www.ceme.gsras.ru/1251/mainnn.htm).

GoRshKOv, G.P. (1947): Earthquakes of Turkmenia Trudy Seismologicheskogo in-ta AN SSSR, 122 (in Russian).

ENCARTA WORLD ATLAS (1998), CD-ROM.

Levitski, G. (Editor) (1902): St. Peterburg, Bull Permanent Central Seismological Commission, pp. 206 (in Russian).

KondORSKAYA, N.V. and N.V. SHEBALIN (Editors) (1977): New Catalog of Large Earthquakes in the USSR Area (Nauka, Publishing House, Moscow), pp. 536 (in Russian).

KonDORSKAYA, N.V. and N.V. SHEBALIN (Editors) (1982): New Catalog of Strong earthquakes in the USSR from ancient times through 1977 (Boulder, U.S.A.), pp. 608.

MALLET, R.W. (1858): Fourth report upon the facts and theory of earthquake phenomena, Report of 28th Meeting of British Association for the Advancement of Science (John Murray, London), 1-136 (plateXI).

MaLINOVSKIY, N.V. (1935): Katalog zemletryaseniy v ASSR, Baku, Catalogue of earthquakes in ASSR (in Russian).

Mushketov, I.V. (1890): Vernenskoe zemletryaseniy 28 maya (9 iunya) $1887 \mathrm{~g}$. (The Verniy earthquake of May 28 (June 9), 1887), Trudy Geologicheskogo Komiteta, X (1), pp. 154 (in Russian).

MushKetOV, I.V. and A.P. ORLOV (1893): Katalog zemletryaseniy Rossiyskoi Imperii (Catalogue of earthquakes in Russian Empire), Zapiski RGO, 26, pp. 582 (in Russian).
Ogajanov, V.A., L.S. Chepkunas, R.S. Mikhailova, S.V. SOLOMIN and A.V. USANOVA (2001): O kataloge zemletryaseniy Srednego i Nizhnego Povolzhya, Zemletryaseniya Severnoy Evrazii v 1995 g. (On earthquake catalogue of Middle and Lower Volga), Moscow, 119-127 (in Russian).

Perrey, A. (1843): Nouvelles recherches sur les tremblements de terre ressentis en Europe, et dans les parties de l'Afrique et de l'Asie de 1801 à juin 1843, Comptes Rendus Acad. Sc., Paris.

Rebai, S., H. Philip, L. Dorbath et al. (1993): Active tectonics in the Lesser Caucasus: coexistence of compressive and extensional structures, Tectonophysics, 12 (5), 1089-1114.

SHEBALIN, N.V. (1961): Ballnost, magnituda i glubina ochaga zemletryseniy (Intensity, magnitude and source depth of earthquakes), Zemletryseniya $v$ SSSR (Izd-vo AN SSSR), 126-138 (in Russian).

Shebalin, N.V. (Editor) (1974): Atlas izoseist zemletryseniy k Novomu katalogu (Archive of Strong eq. Lab., UIPE RAS, Moscow).

Shebalin, N.V. and R.E. TAtevossian (1997): Catalogue of large historical earthquakes of the Caucasus, in Historical and Prehistorical Earthquakes in the Caucasus, edited by D. GiaRdini and S. BALASSANIAN, ILP Publication 333, NATO ASI Ser. 28 (Kluwer Academic Publishers), 201-232.

SchmidT, S.O. (Editor) (1998): Moskva, in Enciclopedia (Bol'shaya Rossiyskaya Entsiklopediya Publ., Moscow), p. 974 (in Russian).

STEPANYAN, V.A. (1942): Istoricheskiy obzor o zemletryseniyakh Armenii $i$ v prilegaushchikh rayonakh (Historical review on earthquakes in Armenia and adjacent regions), (Erevan, izd-vo AN Arm. SSR), (in Russian).

Stucchi, M., P. Albini, R. Camassi, R.M.W. Musson and R. TATEVOSSIAN (2001): Main results of the project BEECD «A Basic European Earthquake Catalogue and a Database for the evaluation of long-term seismicity and seismic hazard», in Seismic risk in the European Union, vol. III (Brussels-Luxembourg).

TAtevossian, R.E. and N.G. Mokrushina (2003): Istoricheskaya seismichnost Srednego Povolzhya (Historical seismicity of Middle Volga), Fizika Zemli, 3, 1-29 (in Russian).

Tatevossian, R.E., P. Albini, R. Camassi, N.G. Mokrushina, N.V. Shebalin and A.E. Petrossian (1997): Analysing and improving supporting dataset of the Akhalkalak, December 31, 1899, earthquake, in Historical and Prehistorical Earthquakes in the Caucasus, edited by D. GIARDINI and S. BALASSANIAN, ILP Publication 333, NATO ASI Ser. 28 (Kluwer Academic Publishers), 383-400.

Tatevossian, R.E., S.S. Arefiev and K.G. PletneV (2002): Macroseismic survey of the Salsk (Russian platform) earthquake of 22 May 2001, Russian J. Earth Sci., 4 (2), 163-169.

Ulomov, V.I. (Editor) (1993): Katalog zemletryseniy Severnoy Evrazii, Seismichnost $i$ seismicheskoe rayonirovanie Severnoy Evrazii (Catalogue of earthquakes in Northern Eurasia), vol. 1, pp. 302 (in Russian).

VolodikHIN, D. (Editor) (1995): Istoriya Rossii. Ot drevnikh slavyan do Petra Velikogo (History of Russia, From ancient Slavons up to Peter the Great), in Ensiclopedia (Moscow, Avanta+), vol. 5, part I, p. 670 (in Russian). 
Volodikhin, D. (Editor) (1997): Istoriya Rossii. Ot dvortsovykh perevorotov do epokhi Velikikh reform (History of Russia, From palace revolutions up to the epoch of Great reforms), in Ensiclopedia (Moscow, Avanta+), vol. 5, part II, p. 702 (in Russian).
Zalesskiy, K., E. AnAN'EVA and D. Volodikhin (Editors) (2001): Rossiyskie stolitsy, Moskva i Sankt-Peterburg (Russian capitals Moscow and Saint-Petersberg), in Ensiclopedia (Moscow, Avanta+), additional vol., p. 445 (in Russian). 